\title{
KERJA ILMIAH SISWA SMP DAN SMA MELALUI AUTHENTIC PROBLEM BASED LEARNING (APBL)
}

\author{
Sudi Dul Aji \\ Muhammad Nur Hudha \\ Pendidikan Fisika, Fakultas Sains dan Teknologi, Universitas Kanjuruhan Malang \\ e-mail: $\underline{\text { sudi@unikama.ac.id , muhammadnurhudha@unikama.ac.id }}$
}

\begin{abstract}
Abstrak
Kerja ilmiah atau scientific approach terhadap IPA/Fisika harus muncul dalam tujuan pembelajaran pada tingkat SMP dan SMA. Kenyataan dilapangan menunjukkan kerja ilmiah siswa SMA pada pelajaran Fisika dan IPA di SMP masih rendah. Dibutuhkan pembelajaran yang menekankan kerja ilmiah pada setiap proses pembelajaran. Penelitian ini bertujuan untuk mendeskripsikan pembelajaran authentic Problem Based Learning (aPBL) dan kerja ilmiah siswa SMP dan SMA. Penelitian ini menggunakan desain penelitian tindakan kelas dari Kemmis \& Mc Taggart dengan tahapan; indentifikasi masalah, perencanaan tindakan, pelaksanaan tindakan, observasi, dan refleksi. Keterlaksanaan authentic Problem Based Learning (aPBL) diukur menggunakan Lembar Keterlaksanaan Pembelajaran dan kerja ilmiah diukur dengan rubrik. Data-data yang diperoleh dari hasil penelitian dianalisis secara kualitatif dan kuantitatif. Hasil penelitian menunjukkan peningkatan persentase ratarata keterlaksanaan authentic Problem Based Learning (aPBL) baik SMP dan SMA dan persentase rata-rata kerja ilmiah siswa SMP dan SMA. Indikator kerja ilmiah meliputi menggunakan alat dan bahan, mengumpulkan data, menganalisis data, menyimpulkan dan mengkomunikasikan hasil eksperimen. Dengan demikian, authentic Problem Based Learning (aPBL) dapat meningkatkan kerja ilmiah siswa SMP dan SMA.
\end{abstract}

Kata Kunci: kerja ilmiah, aPBL

Kerja ilmiah atau scientific approach terhadap IPA/Fisika harus muncul dalam tujuan pembelajaran pada tingkat SMP dan SMA (Ullmer, 2011; Wieman, 2007; Wenning, 2011; Hudha, 2014). Kerja ilmiah terdiri dari keterampilan hands-on dan minds-on atau proses mental, sehingga kemampuan ini tidak datang secara otomatis tetapi perlu latihan (Wenning, 2007:22; Aji \& Hudha, 2015).

Kerja ilmiah dapat dikembangkan didalam pelajaran IPA/Fisika (Hudha, 2014). Kerja ilmiah merupakan kegiatan yang mengacu pada cara-cara ilmuwan dalam mempelajari dunia dan memberikan penjelasan berdasarkan fakta ilmiah (Wenning, 2007:21; Hudha, 2014). Kerja ilmiah yang biasanya dikembangkan dalam riset pendidikan fisika meliputi mendefinisikan masalah; menyatakan hipotesis; merancang percobaan; mengumpulkan dan menganalisis data; mengevaluasi atau menyampaikan hasil percobaan; dan menyimpulkan (Etkina dkk, 2006; Karelina \& Etkina, 2007; Hudha, 2014).

Kenyataan dilapangan menunjukkan kerja ilmiah siswa SMA pada pelajaran Fisika masih rendah. Hal ini juga didukung penelitian sebelumnya bahwa kerja ilmiah pada tingkat SMA masih perlu dikembangkan untuk meminimalisir terjadi kesalahan konsep pada siswa (Hudha, 2014). Kesalahan konsep pada siswa nantinya berpengaruh terhadap prestasi siswa.

Masalah lain yang muncul pada saat pelaksanaan pembelajaran IPA di SMP adalah kemampuan kerja ilmiah siswa yang masih rendah. Hal ini disebabkan karena pada saat pembelajaran guru lebih sering melakukan pembelajaran di ruang kelas dari pada di laboratorium, dengan kata lain siswa hanya menerima konsep “jadi” saja. Siswa 
harus percaya dengan apa yang disampaikan guru tanpa ada proses pembuktian bagaimana cara memperoleh konsep tersebut, hal inilah yang menyebabkan siswa mudah melupakan topik pelajaran yang telah mereka pelajari. Selain itu kemampuan siswa dalam kerja ilmiah seperti menggunakan alat, mengumpulkan data, atau melakukan percobaan kurang dilatihkan oleh guru. Ini terlihat pada saat melaksanakan percobaan dengan menggunakan LKS, banyak kelompok siswa yang melakukan percobaan tidak sesuai langkah-langkah prosedur percobaan yang sudah tertera pada LKS. Sehingga menyebabkab data yang mereka dapatkan tidak sesuai dengan tujuan dari percobaan dan akhirnya dalam membuat kesimpulan masih belum tepat.

Menyingkapi permasalahan yang ada maka dibutuhkan sebuah solusi alternatif. Solusi alternatif ini memungkinkan dapat mencakup dan memenuhi semua kebutuhan yang ada dilapangan. Solusi alternatif tersebut adalah dengan menggunakan sebuah model berbasis konstruktivistis yang dapat mengembangkan kerja ilmiah mahasiswa (Aji \& Hudha, 2015). Salah satu model tersebut adalah model PBL (problem based learning) (Yuliati, 2008; Sanjaya, 2010; Trianto, 2011; Arends, 2012; Aji \& Hudha, 2015). Model PBL adalah model pembelajaran yang berpusat pada siswa yang menggunakan masalah autentik dan bermakna sebagai landasan untuk investigasi dan penyelidikan untuk meningkatkan kemampuan pemecahan masalah, dan untuk memperoleh pengetahuan dan konsep yang esensial (Akinoglu dan Tandagon, 2007; Cheong, 2008; Eggen dan Kauchak, 2012: 307; Arends, 2012: 41; Aji \& Hudha, 2015).

Barrows \& Lynda (2007) mengkolaborasikan model PBL dengan pendekatan authentic learning (Hudha, 2012), yang lebih sering dikenal dengan model authentic Problem Based Learning (aPBL). Penambahan istilah authentic dimaksudkan untuk men-cerminkan tuntutan dunia kerja sebagai proses belajar. Model aPBL didukung dengan adanya pendidikan autentik dan masalah sebagai simulasi keadaan yang akan dihadapi di dunia nyata.

authentic Problem Based Learning (aPBL) adalah sebuah model pembelajaran yang berpusat pada siswa yang merangsang siswa untuk memperoleh dan mengaplikasikan pengetahuan dan keterampilan yang mereka butuhkan (Barrows \& Lynda, 2007; Amelia, 2010; dan Rohanum, 2013). Model aPBL dirancang dengan tujuan agar siswa terampil menggunakan pengetahuan dan keterampilan ketika menghadapi masalah baru serta bekerja secara efektif dalam kelompok (Barrows \& Lynda, 2007). Oleh karena itu, penerapan aPBL diharapkan dapat meningkatkan kerja ilmiah siswa.

Menurut penelitian yang telah dilakukan (Yuliati, 2012; Rohanum, 2013), pembelajaran dengan aPBL dapat meningkatkan hasil belajar dalam aspek kognitif, afektif, dan psikomotor. Peningkatan tersebut terjadi karena aPBL memfasilitasi siswa untuk aktif belajar secara mandiri dengan menggunakan fenomena IPA/Fisika secara langsung. Penelitian lain juga menyatakan, bahwa pembelajaran fisika dengan menggunakan aPBL dapat meningkatkan kreativitas, hubungan inter-personal, dan penguasaan konsep.

\section{METODE PENELITIAN}

Jenis penelitian yang digunakan adalah penelitian tindakan kelas (classroom action research). Penelitian ini dilakukan dalam konteks kelas yang bertujuan 
memperbaiki proses pembelajaran untuk meningkatkan kerja ilmiah siswa SMP dan SMA. Penelitian terdiri dari empat komponen pokok yaitu perencanaan (planning), tindakan (action), pengamatan (observation), dan refleksi (reflection). Rancangan penelitian mengadap-tasi dari bagan Kemmis-Mc Taggart (dalam Arikunto, 2011, 16)

Subjek penelitian adalah siswa SMP dan SMA. Subjek penelitian pada tingkat SMP yaitu siswa kelas VIII-A SMPN 3 Kepanjen semester 1 tahun pelajaran 2015/2016 dengan jumlah siswa 36 orang. Sedangkan subyek penelitian pada tingkat SMA adalah siswa Kelas XIA5 di SMAN 1 Singosari yang menempuh topik Usaha dan Energi semester ganjil tahun akademik 2015/2016. Jumlah siswa 30 orang, terdiri dari 15 siswa laki-laki dan 15 siswa perempuan.

Data dan sumber data pada penelitian ini adalah data keterlaksanaan pembelajaran dan data kerja ilmiah. Data keterlaksanaan pembelajaran meliputi aspek perencanaan, pembelajaran, manjemen kelas, dan penilaian. Data ini diperoleh dari hasil observasi keterlaksanaan pembelajaran setelah menerap-kan authentic Problem Based Learning (aPBL). Sedangkan data kerja ilmiah berupa rubrik pengamatan berdasarkan indikator kerja ilmiah pada setiap akhir siklus, yaitu siklus I dan siklus II. Data ini digunakan sebagai pendukung ketercapaian keberhasilan authentic Problem Based Learning (aPBL). Data ini diperoleh dari sumber yang sama yaitu siswa pada saat authentic Problem Based Learning (aPBL) berlangsung.

\section{HASIL PENELITAN DAN PEMBAHASAN}

A. Keterlaksananan authentic Problem Based Learning (aPBL) pada Siklus I dan Siklus II

\section{SMA}

Hasil observasi keterlaksanaan pembelajaran model pembelajaran authentic Problem Based Learning (aPBL) yang dilakukan oleh peneliti dan siswa mengalami peningkatan dari siklus I ke siklus II. Perhatikan Tabel 1 berikut:

Tabel 1 Peningkatan Keterlaksanaan aPBL SMA

\begin{tabular}{lcc}
\hline \multirow{2}{*}{ Aspek } & \multicolumn{2}{c}{ Persentase } \\
\cline { 2 - 3 } & Siklus I & Siklus II \\
\hline - Perencanaan & $100 \%$ & $100 \%$ \\
- Pembelajaran & $72,92 \%$ & $93,75 \%$ \\
- Manajemen Kelas & $41,67 \%$ & $87,50 \%$ \\
- Penilaian & $91,67 \%$ & $100 \%$ \\
\hline
\end{tabular}

Keterlaksanan aPBL pada siklus I secara keseluruhan sudah berjalan baik. Namun jika dianalisis tiap aspek, aspek manajemen kelas menunjukkan hasil yang kurang signifikan. Pada siklus I aspek manajemen kelas mempunyai nilai yang paling rendah dibandingkan aspek yang lain. Hal ini dikarenakan siswa belum beradaptasi dengan karakteristik pembelajaran aPBL. Padahal manajemen kelas yang baik itu dapat terciptanya suasana kondusif dalam proses pembelajan (Sanjaya, 2010: 24; Hudha, 2012).

\section{SMP}

Mengacu pada persentase keterlaksanaan pembelajaran yang telah diperoleh siklus I dan siklus II pada tingkat SMP, dibuat perbandingan ketercapaian pelaksanaan aPBL untuk tiap aspek yang ditunjukkan pada Tabel 2. Berdasarkan persentase pencapaian aPBL tersebut diperoleh peningkatan dari siklus I dan 
siklus II. Pada tiap siklus juga mengalami peningkatan untuk masing-masing aspek.

Tabel 2 Peningkatan Keterlaksanaan aPBL SMP

\begin{tabular}{lcc}
\hline \multirow{2}{*}{ Aspek } & \multicolumn{2}{c}{ Persentase } \\
\cline { 2 - 3 } & Siklus I & Siklus II \\
\hline - Perencanaan & $100 \%$ & $100 \%$ \\
- Pembelajaran & $70,83 \%$ & $81,25 \%$ \\
- Manajenen Kelas & $62,5 \%$ & $75 \%$ \\
- Penilaian & $66,67 \%$ & $79,17 \%$ \\
\hline
\end{tabular}

Proses pembelajaran aPBL pada mata pelajaran IPA dilakukan dengan cara siswa dilibatkan langsung selama proses pemecahan masalah dengan bersikusi maupun ekperimen. Hal tersebut memicu siswa untuk aktif bertindak maupun berpikir dalam mencari solusi. Sehingga terjadinya peningkatan dalam setiap aspek keterlaksanaan pembelajaran. Sukumaran (2012) juga menegaskan dalam hasil penelitianya bahwa pembelajaran berbasis authentic dapat mempersiapkan siswa dengan orientasi praktis untuk mengembangkan cara pikir yang akan memberikan keahlian kognitif, afektif dan psikomotor. Selain itu, penelitian Yuliati (2011) juga menyatakan bahwa peningkatan kemampuan kognitif, afektif dan psikomotor terjadi karena aPBL memfasilitasi siswa untuk aktif belajar secara mandiri dengan cara memecahkan masalah pada kehidupan nyata.

Selain itu, peningkatan ini menunjukkan bahwa hasil refleksi pada siklus I dapat memperbaiki kekurangan yang terdapat pada pembelajaran siklus I dan diterapkan pada siklus II.

\section{B. Kerja Ilmiah}

\section{SMA}

Penelitian ini juga mengukur peningkatan kemampuan kerja ilmiah siswa. Indikator kerja ilmiah yang digunakan dalam penelitian ini yaitu menggunakan alat dan bahan, mengumpulkan data, menganalisis data, menyimpulkan, dan mengkomunikasikan hasil eksperimen (Hudha, 2014). Kerja ilmiah pada tingkat SMA dapat dilihat pada Tabel 3 berikut ini.

Tabel 3 Peningkatan Kerja Ilmiah SMA

\begin{tabular}{|c|c|c|}
\hline \multirow[t]{2}{*}{ Indikator } & \multicolumn{2}{|c|}{$\begin{array}{c}\text { Perbandingan rata-rata } \\
\text { nilai kerja ilmiah }\end{array}$} \\
\hline & Siklus I & Siklus II \\
\hline $\begin{array}{l}\text { - Menggunakan alat dan } \\
\text { bahan }\end{array}$ & $57,36 \%$ & $92,49 \%$ \\
\hline - Mengumpulkan data & $56,76 \%$ & $88,89 \%$ \\
\hline - Menganalisis data & $55,56 \%$ & $86,49 \%$ \\
\hline - Menyimpulkan & $51,65 \%$ & $86,49 \%$ \\
\hline $\begin{array}{l}\text { - Mengkomunikasikan } \\
\text { hasil eksperimen }\end{array}$ & $62,46 \%$ & $89,49 \%$ \\
\hline
\end{tabular}

Kerja ilmiah pada tingkat SMA sudah mengalami peningkatan yang baik selama proses pembelajaran jika dilihat dari tiap indikator. Topik yang diteliti pada tingkat SMA ini adalah konsep usaha dan energi.

Pembelajaran Fisika dalam pokok bahasan usaha dan energi memiliki banyak penerapan di dalam kehidupan nyata (Pradana, 2014). Berdasarkan hasil obsrvasi awal banyak siswa mengalami kesulitan di dalam menganalisis fenomena kehidupan nyata yang merupakan contoh dari konsep usaha dan energi. Oleh karena itu perlu adanya sebuah metode pembelajaran yang dapat membantu siswa untuk lebih berpikir terhadap fenomena-fenomena yang berhubungan dengan konsep fisika.

\section{SMP}

Kemampuan kerja ilmiah siswa SMP di siklus I mengalami peningkatan pada siklus II. Hal ini disebabkan selama proses pembelajaran siswa dilatih mengembangkan kemampuan kerja ilmiah. Untuk lebih 
jelasnya kerja ilmiah pada tingkat SMP dapat dilihat pada Tabel 4 berikut ini.

Tabel 4 Peningkatan Kerja Ilmiah SMP

Perbandingan rata-rata

Indikator

nilai kerja ilmiah

Siklus I Siklus II

- Menggunakan alat dan

53,70

82,71 bahan

54,01

- Mengumpulkan data

50,62

79,32

- Menganalisis data

56,48

73,77

- Menyimpulkan

75,93

- Mengkomunikasikan

62,35 hasil eksperimen

Kemampuan siswa dalam menggunakan alat dan bahan mengalami peningkatan pada siklus II. Hal ini disebabkan karena pada siklus I kebanyakan siswa baru mengetahui alat yang digunakan dalam topik gaya. Sehingga siswa merasa kesulitan untuk memahami fungsi dari alat percobaan, misalnya neraca pegas. Sedangkan pada siklus II siswa sudah sering melakukan percobaan dan dilatih kerja ilmiah sehingga siswa sudah mampu memahami fungsi alat dan bahan.

Kemampuan siswa dalam mengumpulkan data mengalami peningkatan pada siklus II. Hal ini disebabkan karena pada siklus I kebanyakan siswa belum membaca langkah kerja yang sudah ada pada LKS percobaan, sehingga data yang dikumpulkan oleh siswa tidak sesuai dengan data yang diminta pada LKS. Sedangkan pada siklus II siswa sudah membaca langkah kerja pada LKS percobaan dan dilatih kerja ilmiah sehingga siswa sudah mampu mengumpulkan data dan memahami makna dari data yang diambil.

Kemampuan siswa dalam menganalisis data mengalami peningkatan pada siklus II. Hal ini disebabkan karena pada siklus I siswa belum mampu menunjukan hubungan variabel, misalnya hubungan antara percepatan dengan massa pada Hukum II Newton. Sedangkan pada siklus II siswa sudah mampu menunjukkan hubungan variabel. Oleh karena itu sebaiknya kerja ilmiah perlu diterapkan didalam pem-belajaran IPA. Kerja ilmiah terdiri dari proses pola pikir sehingga ketrampilan ini tidak datang secara otomatis tetapi perlu latihan (Wenning, 2007:2).

Kemampuan siswa dalam menyimpulkan mengalami peningkatan pada -siklus II. Hal ini dikarenakan siswa dan guru bersama-sama untuk membuat kesimpulan. Pemberian bantuan ini disebabkan karena pada siklus I siswa mengalami kesulitan dalam menganalisis data, sehingga berdampak pada indikator menyimpulkan. Pemberian bim-bingan dalam membuat kesimpulan sangat membantu siswa karena membuat siswa memiliki konsepsi yang benar.

Kemampuan siswa dalam mengkomunikasikan hasil percobaan juga mengalami peningkatan pada siklus II.

\section{SIMPULAN}

Penerapan authentic Problem Based Learning (aPBL) pada SMP dan SMA telah berjalan sesuai dengan rancangan yang telah dibuat. Aspek keterlaksanaan authentic Problem Based Learning (aPBL) meliputi perencanaan, pembelajaran, manajemen kelas, dan penilaian. Model aPBL dalam penelitian ini terdiri dari 7 tahap sebagai berikut: (1) pendahuluan (orientation), (2) menyajikan permasalahan (encountering the problem), (3) membuat hipotesa dan menetukan sumber belajar (talking the lerning issues), (4) mendiskusikan informasi dengan kelompok lain secara kritis (reiterating and reassessing the problem), 
(5) membuat ringkasan dari hasil pembahasan (summarizing and knowledge abstraction), (6) mendiskusikan tentang apa yang harus dilakukan untuk membantu masalah yang dialami anggota kelompoknya (conducting self-and peer-evaluation), dan (7) guru melakukan evaluasi kinerja kelompok (conducting turor evaluation).

Penerapan authentic Problem Based Learning (aPBL) dapat meningkatkan kemampuan kerja ilmiah siswa SMP dan SMA. Peningkatan ini dilihat dari persentase hasil rata-rata kerja ilmiah siswa. Kemampuan kerja ilmiah siswa berasal dari observasi kerja ilmiah selama pembelajaran. Aspek kerja ilmiah yang dilatihkan dalam penelitian ini, yaitu menggunakan alat dan bahan, mengumpulkan data, menganalisis data, menyimpulkan dan mengkomunikasikan hasil eksperimen.

\section{PUSTAKA RUJUKAN}

Aji, S.D \& Hudha, M.N. 2015. Dampak PBL Terhadap Kerja Ilmiah Mahasiswa Pada Perkuliahan Pengembangan Media Pembelajaran. Jurnal Inspirasi, Vol 5 (2).

Akinoglu, O \& Tandagon, R. Ö. 2007. The Effects of Problem-Based Active Learning in Science Education on Students' Academic Achievement, Attitude and Cocept Learning. Eurasia Journal of Mathematics, Science \& Technology Education, 2007, 3 (1), 71-81.

Amelia, R. 2010. Penerapan Model Pembelajaran Learning Cycle (LC) 5 Fase Berbantuan Peta Konsep Untuk Meningkatkan Kemampuan Kerja
Ilmiah dan Prestasi Belajar Siswa Kelas XI-IPA2 SMAN 10 Malang Tahun Ajaran 2009-2010. Skripsi tidak diterbitkan. Malang: Program Studi Pendidikan Fisika Universitas Negeri Malang.

Arends, R. I. 2012. Learning to Teach: 9th edition. New York: McGraw-Hill.

Arikunto, S. 2011. Penelitian Tindakan Kelas. Jakarta: Bumi Aksara

Barrows, H.S. \& Lynda, W.K.N. 2007. Principles and Practice of aPBL. Jurong: Pearson Prentice Hall

Cheong, F. 2008. Using Problem-Based Learning Approach to Teach an Intelligent systems Course. Journal of Information technology Education Vol. 7.

Eggen, P \& Kauchak, D. 2012. Stategi dan Model Pembelajaran: Mengajarkan Konten dan Keterampilan Berfikir. Jakarta: PT Indeks.

Etkina, E., Van Heuvelen, A., WhiteBrahmia, S., Brookes, D.T., Gentile, M., Murthy, S., Rosengrant,D.,\& Warren,. A. 2006. Scientific abilities and their assessment. Physics Education Research, 2(2) : 1-15

Hudha, M. N. 2012. Authentic Learning Untuk Meningkatkan Kemampuan Berfikir Kritis Calon Guru Fisika. Makalah, Seminar Nasional MIPA dan Pembelajaran. Fakultas Matematika dan Ilmu Pengetahuan Alam Universitas Negeri Malang. 
Hudha, M. N. 2014. Dampak Authentic Problem Melaliu Integrative Learning Terhdadap Perubahan Konseptual dan Kerja Ilmiah Fisika Siswa SMA Pada Topik Gerak Lurus. Pascasarjana Program Studi Pendidikan Fisika. Universitas Negeri Malang. Tesis tidak diterbitkan

Karelina, A \& Etkina, E.2007 Acting like a physicist: Student approach study to experimental design. Physics Education Research 3(2);1-12

Pradana, M.R.A. 2014. Pengaruh Metode Herrmann Whole Brain Teaching Terhadap Kemampuan Berpikir Kritis Fisika dan Model Mental Siswa di Dalam Pembelajaran Fisika Siswa Kelas Xi IPA. Pascasarjana Program Studi Pendidikan Fisika.Universitas Negeri Malang. Tesis tidak diterbitkan

Rohanum, E. 2013. Pengaruh AuthenticProblem Based Learning Terhadap Kemampuan Pemecahan Masalah Fisika Ditinjau Dari Kemampuan Awal Peserta Didik MAN 1 Malang. Tesis tidak diterbitkan. Malang: PPs UM

Sanjaya, W. 2010. Strategi Pembelajaran Berorientasi Standar Pendidikan. Bandung: Kencana Prenada Media Group.

Sukumaran. 2012. Authentic learning for Acquiring Competency in Profesional Education. Journal of Modern Education, 2 (1): 62-67,

Trianto.2011. Model-model Pembelajaran Inovatif Berorientasi Konstruktivistik. Jakarta: Prestasi Pustaka.
Ullmer, J.H.2011. The scientific method of Sir William Petty. Erasmus Journal for Philosophy and Economics, 4(2) 119.

Wieman,C. 2007."Why Not Try? a Scientific Approach to Science Education?". Change Magazine, 39(5) 9-15,

Wenning, C. J .2007. Assessing Inquiry Skill as a Component Of Scientific Literacy. Journal Physics Teacher Education Online, 4(2) : 21-24,

Wenning, C. J. 2011. "Experimental Inquiry in Introductory Physics Courses". Journal Physics Teacher Education Online, 6(2): 2-8,

Yuliati, L. 2008. Model-model Pembelajaran Fisika: Teori dan Praktek. Malang: Lembaga Pengembangan dan Pembelajaran UM.

Yuliati, L. 2012. Authentic Problem Based Learning untuk Meningkatkan Hasil Belajar Fisika Siswa SMA. Makalah, Seminar Nasional MIPA dan Pembelajaran. Fakultas Matematika dan Ilmu Pengetahuan Alam Universitas Negeri Malang 